Brit. F. vener. Dis. (1969), 45, 235.

\title{
TREATMENT OF GONORRHOEA BY ONE ORAL DOSE OF AMPICILLIN AND PROBENECID COMBINED*
}

\author{
BY \\ T. GUNDERSEN, K. ÖDEGAARD AND H. C. GJESSING \\ Bureau of Public Health, Department of Venereal Diseases, and National Institute of Public Health, \\ Department of Bacteriology, Oslo, Norway
}

It has been shown (Ödegaard, 1962) by sensitivity testing in vitro that the effect of ampicillin on most gonococcal strains is somewhat weaker than that of penicillin $G$, but the effect on strains less sensitive is better with ampicillin than with penicillin G. Reyn and Bentzon (1968), in support of this, found that the 50 per cent. inhibitory concentrations for the naturally-occurring more sensitive strains were about twice as high with ampicillin as with sodium penicillin $G$, whereas an opposite tendency was observed in the less sensitive strains.

As the great majority of relapses after treatment with penicillin occur in patients infected with gonococci with reduced sensitivity to penicillin, it is therefore possible that ampicillin could be an effective remedy in the treatment of gonorrhoea. This has proved to be the case. Willcox (1963) found a failure rate of 11.9 per cent. in male patients with uncomplicated gonorrhoea treated with a single oral dose of $0.5 \mathrm{~g}$. ampicillin, which proved comparable to the results achieved with single injections of aqueous procaine penicillin. Willcox (1964) also found that the results of ampicillin given orally were somewhat better than those obtained with ampicillin by injection. Alergant (1963), administering ampicillin as a single $1 \mathrm{~g}$. oral dose in the treatment of uncomplicated gonorrhoea in males, had a cure rate of 95 per cent., which was higher than that obtained with any previous oral preparation of penicillin, and he considered ampicillin to be a suitable alternative to penicillin by injection in the treatment of gonorrhoea. Marmell, Sills, Brown, and Prigot (1964) obtained excellent results with ampicillin given in divided doses of $1 \mathrm{~g}$. When Gjessing and Ödegaard (1965) treated 500 males with one oral dose of $1 \mathrm{~g}$. ampicillin combined with one simultaneous injection of 600,000 units procaine penicillin the relapse frequency was 3 per cent., whereas 500 patients

^Received for publication February 18, 1969. treated with procaine penicillin only showed a relapse rate 11.6 per cent.

Probenecid, which impedes the excretion of penicillin from the body and thus causes a higher serum concentration and a longer duration of penicillinaemia, was given, together with an intramuscular injection of sodium penicillin $G$, to gonorrhoea patients by Jensen, Kvorning, and Nörredam (1963) with good results. Lomholt and Berg (1966) and Olsen and Lomholt (1968) treated gonorrhoea patients in Greenland with an oral dose of $1 \mathrm{~g}$. probenecid, followed after 30 minutes by an intramuscular injection of 5 million units sodium penicillin $G$ dissolved in $8 \mathrm{ml}$. of a 0.5 per cent. solution of lidocaine. This method, as shown by Schmidt and Roholt (1965), can give an initial penicillinaemia of up to 200 units $/ \mathrm{ml}$., and after 8 hours, an average concentration of 5 units $/ \mathrm{ml}$. Of the 832 patients treated, there were only eight who relapsed; all had had sexual intercourse after the first treatment and all were cured after a repetition of the treatment. It is therefore highly probable that these cases were not relapses but re-infections and that the cure rate was 100 per cent.

We have not been able to find any publication describing the use of an oral dose of ampicillin and probenecid combined in the treatment of gonorrhoea. The object of this paper is to show the results of such treatment.

\section{Material and Methods}

1,000 male patients with acute uncomplicated gonorrhoea seen at the Oslo Board of Health, Department of Venereal Diseases, between January, 1967, and July, 1968, are included in the series.

The diagnosis was based on smears showing leucocytes with intracellular Gram-negative diplococci and positive cultures where the diagnostic criteria were typical oxidase positive colonies of Gram-negative diplococci, no growth on nutrient agar, and acid formation from glucose, but not from maltose and sucrose. 
Sensitivity testing of the gonococci isolated was undertaken as part of the laboratory routine. The sensitivity to penicillin $\mathrm{G}$ was tested by a plate dilution method with "chocolate" agar medium containing successively doubling dilutions of sodium penicillin G, giving a range of penicillin concentrations from 0.0075 to 2 units $/ \mathrm{ml}$. The minimum inhibitory concentration (MIC) was registered as the minimum concentration at which no growth could be observed with the naked eye. We have considered strains with an MIC $\geqslant 0.125$ units $/ \mathrm{ml}$. as having a decreased sensitivity to penicillin. A paper disc method was used for four other antibiotics and for sulphonamide. The methods of sensitivity testing were otherwise as described in a previous paper (Ödegaard and Gjessing, 1967).

\section{Treatment}

500 patients were given one oral dose consisting of $2 \mathrm{~g}$. ampicillin (Doctacillin (1) ASTRA) and $1 \mathrm{~g}$. probenecid (Probecid (1) ASTRA) (Series I). Another 500 patients were treated with one intramuscular injection consisting of 1.2 million units procaine penicillin and 1 million units sodium penicillin G (Astracillin Special (B) ASTRA) (Series II).

\section{Follow-up}

All the patients were asked to return for follow-up after 1 week and again after 2 weeks, and to refrain from sexual intercourse during this period. Letters were sent to patients who did not return voluntarily, and if this proved unsuccessful they were ordered to come by the police. After 30 days had elapsed, those who had evaded follow-up were designated "not followed up". Patients were considered cured if gonococci were not demonstrated at both follow-up examinations.

Distinction between Relapse and Re-infection

A case was considered to have relapsed if gonococci were demonstrated at the first follow-up visit, and the urethral discharge was unchanged or only temporarily reduced. Classification as re-infection depended upon the finding of a positive culture after a previous negative culture, and the admission of sexual intercourse during the follow-up period with the appearance of the symptoms at the appropriate time. In some cases re-infection may also be indicated by changes in the sensitivity pattern of the cultures isolated before and after treatment (Gjessing and Ödegaard, 1962; Reyn and Bentzon, 1963). Even with very careful appraisal, there was a doubt in a few instances whether relapse or re-infection had occurred.

\section{Results}

The results are shown in the Table.

\section{Series I}

Of the 500 patients treated with ampicillin/ probenecid, 437 were followed up. Six had a relapse (1.4 per cent. of those followed, or 1.2 per cent. of all those treated). All cases of relapse occurred in patients infected with gonococci showing a decreased sensitivity to sodium penicillin G (MIC $0.125 \mathrm{unit} / \mathrm{ml}$. or higher), the relapse frequency being $4 \cdot 2$ per cent. of the 143 such patients followed, or 3.6 per cent. of the 166 such patients treated.

\section{Series II}

Of the 500 patients treated with one intramuscular injection of 1.2 million units procaine penicillin and 1 million units sodium penicillin $G, 441$ were followed and there were seventeen relapses (3.8 per cent. of those followed or 3.4 per cent. of all those treated). All the relapses occurred among the 179 patients infected with gonococci showing a

TABLE

COMPARISON BETWEEN ONE ORAL DOSE OF 2 g. AMPICILLIN WITH 1 g. PROBENECID AND ONE INTRAMUSCULAR INJECTION OF 1.2 MILLION UNITS PROCAINE PENICILLIN WITH 1 MILLION UNITS SODIUM PENICILLIN G

\begin{tabular}{|c|c|c|c|c|c|c|c|c|c|c|c|}
\hline & & \multicolumn{5}{|c|}{ I ( 2 g. ampicillin +1 g. probenecid $)$} & \multicolumn{5}{|c|}{ II ( 1.2 m.u. procaine penicillin +1 m.u. sodium } \\
\hline \multirow{3}{*}{\multicolumn{2}{|c|}{ Series }} & \multirow{3}{*}{$\begin{array}{l}\text { No. of } \\
\text { Patients }\end{array}$} & \multirow{3}{*}{$\begin{array}{l}\text { Not } \\
\text { followed } \\
\text { up }\end{array}$} & \multicolumn{3}{|c|}{ Followed-up } & \multirow{3}{*}{$\begin{array}{l}\text { No. of } \\
\text { Patients }\end{array}$} & \multirow{3}{*}{$\begin{array}{l}\text { Not } \\
\text { followed- } \\
\text { up }\end{array}$} & \multicolumn{3}{|c|}{ Followed-up } \\
\hline & & & & \multirow{2}{*}{$\begin{array}{l}\text { Gc. } \\
\text { neg. }\end{array}$} & \multicolumn{2}{|c|}{ Gc. pos. } & & & & Gc & pos. \\
\hline & & & & & Relapse & $\begin{array}{c}\mathrm{Re}- \\
\text { infection }\end{array}$ & & & neg. & $\overline{\text { Relapse }}$ & $\begin{array}{c}\mathrm{Re}- \\
\text { infection }\end{array}$ \\
\hline \multirow{2}{*}{$\begin{array}{l}\text { MIC of } \\
\text { sodium } \\
\text { penicillin } \\
\text { G } \\
\text { (units/ } \\
\text { ml.) }\end{array}$} & $\begin{array}{c}\text { Less } \\
\text { sensitive } \\
2.0 \\
1.0 \\
0.5 \\
0.25 \\
0.125\end{array}$ & $\left.\begin{array}{r}9 \\
27 \\
52 \\
45 \\
33\end{array}\right\} 166$ & $\begin{array}{r}0 \\
4 \\
10 \\
6 \\
3\end{array}$ & $\begin{array}{r}8 \\
20 \\
38 \\
35 \\
27\end{array}$ & $\left.\begin{array}{l}1 \\
2 \\
1 \\
0 \\
2\end{array}\right\} 6$ & $\begin{array}{l}0 \\
1 \\
3 \\
4 \\
1\end{array}$ & $\left.\begin{array}{r}7 \\
21 \\
51 \\
56 \\
44\end{array}\right\} 179$ & $\begin{array}{l}0 \\
4 \\
8 \\
5 \\
3\end{array}$ & $\begin{array}{r}3 \\
12 \\
34 \\
47 \\
41\end{array}$ & $\left.\begin{array}{l}4 \\
4 \\
8 \\
1 \\
0\end{array}\right\} 17$ & $\begin{array}{l}0 \\
1 \\
1 \\
3 \\
0\end{array}$ \\
\hline & $\begin{array}{c}\text { Sensitive } \\
0.06 \\
0.03 \\
\leqslant 0.015\end{array}$ & $\left.\begin{array}{r}65 \\
196 \\
73\end{array}\right\} 334$ & $\begin{array}{r}8 \\
23 \\
9\end{array}$ & $\begin{array}{r}49 \\
164 \\
58\end{array}$ & $\left.\begin{array}{l}0 \\
0 \\
0\end{array}\right\} 0$ & $\begin{array}{l}8 \\
8 \\
7\end{array}$ & $\left.\begin{array}{r}48 \\
189 \\
84\end{array}\right\} 321$ & $\begin{array}{l}10 \\
18 \\
11\end{array}$ & $\begin{array}{r}36 \\
162 \\
69\end{array}$ & $\left.\begin{array}{l}0 \\
0 \\
0\end{array}\right\} 0$ & $\begin{array}{l}2 \\
9 \\
4\end{array}$ \\
\hline Total & & 500 & 63 & 399 & 6 & 32 & 500 & 59 & 404 & 17 & 20 \\
\hline
\end{tabular}


decreased sensitivity to penicillin, the relapse frequency in this group being 10.6 per cent. of the 159 followed, or 9.5 per cent. of the 179 treated.

\section{Side-effects}

There appeared to be no side-effects in the patients treated with ampicillin/probenecid. In Series II, on the other hand, two patients developed anaphylactoid shock approximately 5 minutes after the intramuscular injection. They were treated with adrenaline subcutaneously and corticosteroids intravenously and were admitted to hospital, where both recovered. There was also one case of urticaria in Series II.

\section{Discussion}

The advantages of treatment with ampicillin and probenecid combined are:

(1) Penicillin injections are avoided so that the danger of anaphylactoid reactions and the likelihood of penicillin sensitization is reduced (Northington, 1964).

(2) As the treatment is given in one dose only and under supervision, the patient cannot discontinue treatment or save the tablets for use on a later occasion.

(3) To obtain the maximum effect, probenecid tablets should be taken approximately half an hour before an intramuscular injection of penicillin, which is a disadvantage in a busy out-patient department. This is avoided when both drugs are administered orally as they can then be taken simultaneously.

We consider a relapse frequency of 1.2 to 1.4 per cent. to be such a good result that we have continued this treatment for all male patients with uncomplicated gonorrhoea.

\section{Summary}

In the cases of 500 male patients with uncomplicated gonorrhoea treated with 2 g. ampicillin combined with $1 \mathrm{~g}$. probenecid in one oral dose, there were six failures (1.2 per cent. of those treated; 1.4 per cent. of those followed).

500 males with uncomplicated gonorrhoea who received our standard treatment of one intramuscular injection of a combination of 1.2 million units procaine penicillin and 1 million units sodium penicillin G, served as controls. There were seventeen failures ( 3.4 per cent. of those treated; 3.8 per cent. of those followed).

All the failures in both series occurred amongst patients infected with gonococci with decreased sensitivity to sodium penicillin G.

\section{REFERENCES}

Alergant, C. D. (1963). Brit. F. vener. Dis., 39, 225.

GJessing, H. C., and ÖdegaARD, K. (1962). Ibid., 38, 26.

- (1965). Ibid., 41, 48.

Jensen, P. E., Kvorning, S. A., and Nørredam, K. (1963). "Proc. North. Derm. Soc., 1962". Copyright by Acta derm.-venereol. (Stockh.), p. 49.

LOMHOLT, G., and BerG, O. (1966). Brit. F. vener. Dis., 42, 1.

Marmell, M., Sills, J. R., Brown, C. D., and Prigot, A. (1964). N.Y. St. F. Med., 64, 985.

NoRTHINGTON, J. M. (1964). Clin. Med., 71, 803.

ÖDEGAARD, K. (1962). T. norsk. Loegeforen., 82, 55.

- and GJEssing, H. C. (1967). Brit. F. vener. Dis., 43, 284.

Olsen, G. A., and LomHolt, G. (1968). Ugeskr. Laeg., $130,1465$.

Reyn, A., and Bentzon, M. W. (1963). "Proc. North. Derm. Soc., 1962". Copyright by Acta derm.venereol. (Stockh.), p. 31.

- - (1968). Brit. f. vener. Dis., 44, 140.

SchmidT, H., and RoHolT, K. (1965). Ugeskr. Laeg., 127, 478.

Willcox, R. R. (1963). Brit. F. vener. Dis., 39, 164. (1964). Ibid., 40, 261.

Traitement de la gonococcie par une dose unique d'ampicilline associée au probenecid

\section{RÉSUMÉ}

Dans 500 cas de gonococcie masculine non compliquée traités par $2 \mathrm{~g}$. d'ampicilline associée à $1 \mathrm{~g}$. de probenecid en une seule prise orale, il y eut six échecs (soit 1,2 pour cent des traités, 1,4 pour cent des cas suivis).

500 homme atteints de gonococcie non compliquée qui avaient reçu le traitement standard, c'est à dire une injection intramusculaire d'une association de 1,2 millions d'unités de pénicilline-procaïne et de 1 million d'unités de pénicilline $G$ sodique, servaient de témoins; il y eut 17 échecs $(3,4$ pour cent des traités, 3,8 pour cent des cas suivis).

Tous les échecs dans ces deux séries survinrent chez des malades infectés par des gonocoque de faible sensibilité à la pénicilline $\mathrm{G}$. 